\title{
Diagnostic Whole-Body Scan May Not Be Necessary for Intermediate-Risk Patients with Differentiated Thyroid Cancer after Low-Dose (30 mCi) Radioactive Iodide Ablation
}

Eon Ju Jeon, Eui Dal Jung

Department of Internal Medicine, Catholic University of Daegu School of Medicine, Daegu, Korea

Background: A diagnostic whole-body scan (WBS) is recommended 6 to 12 months after total thyroidectomy and radioactive iodide ablation in intermediate- or high-risk patients with differentiated thyroid cancer (DTC). The aim of this study was to evaluate the necessity of a diagnostic WBS after radioactive iodide ablation in intermediate-risk patients with DTC.

Methods: A total of 438 subjects were included in the study: 183 low-risk subjects and 255 intermediate-risk subjects according to the American Thyroid Association guideline. All subjects diagnosed with DTC received 1,100 MBq (30 mCi) activity of radioiodine (I-131) following total thyroidectomy. On follow-up, all subjects underwent a diagnostic I-131 WBS after thyroid hormone withdrawal.

Results: After initial radioactive iodide ablation, $95.1 \%$ of low-risk patients and $91.4 \%$ of intermediate-risk patients showed no uptake on diagnostic WBS $(P=0.135)$. Intermediate-risk patients with stimulated thyroglobulin $(\mathrm{Tg})$ levels higher than $2.0 \mathrm{ng} / \mathrm{mL}$ showed a greater rate of radioactive iodine uptake on diagnostic WBS. Four intermediate-risk patients showed recurrence during the 16 to 80 months follow-up period. Three of the four patients with recurrence showed no uptake on diagnostic WBS and had a stimulated Tg level less than $2.0 \mathrm{ng} / \mathrm{mL}$.

Conclusion: A diagnostic I-131 WBS after radioactive iodide ablation in intermediate-risk patients with DTC may not be necessary. A large prospective study is necessary to determine the necessity of diagnostic WBS in intermediate-risk patients with DTC.

Keywords: Ablation; Iodides; Radioactivity; Thyroid neoplasms

\section{INTRODUCTION}

Differentiated thyroid carcinoma accounts for $90 \%$ of thyroid cancers including papillary carcinoma and follicular carcinoma. Major treatment includes surgical treatment and radioiodine ablation, and can bring positive consequences with a greater than $90 \%$ survival rate $[1,2]$. Complete ablation of residual thyroid tissue by radioiodine infusion after total thyroidectomy can decrease the risk of local recurrence and increase the long-term survival rate [3-8]. Recently, the frequency of thyroid nodules and differentiated thyroid carcinomas has increased, and a number of clinical studies have been conducted.
Received: 5 March 2013, Accepted: 20 August 2013

Corresponding author: Eui Dal Jung

Department of Internal Medicine, Catholic University of Daegu School of Medicine, 33 Duryugongwon-ro 17-gil, Nam-gu, Daegu 705-718, Korea Tel: +82-53-650-4098, Fax: +82-53-651-4009, E-mail: jed15@cu.ac.kr
Copyright $(2014$ Korean Endocrine Society

This is an Open Access article distributed under the terms of the Creative Commons Attribution Non-Commercial License (http://creativecommons.org/ licenses/by-nc/3.0/) which permits unrestricted non-commercial use, distribution, and reproduction in any medium, provided the original work is properly cited. 
Consequently, the American Thyroid Association (ATA) published revised guidelines on practice recommendations [4,9, 10]. In these guidelines, the staging system for thyroid cancer uses the American Joint Committee on Cancer/International Union against Cancer-Tumor, Lymph node, Metastasis (AJCC/ UICC-TNM) as a predictor of mortality. Therefore, it is not suitable for determining the intensity of follow-ups and has limited impact on risk of recurrence. For these reasons, patients are classified as low-risk, intermediate-risk, and high-risk groups according to the risk of recurrence [4,11-14]. Diagnostic whole-body scans (WBSs) performed on patients with radioiodine thyroid ablation for 6 to 12 months have low sensitivity, so although it is not necessary for low-risk patients [15-22], it can be useful for intermediate-risk and high-risk patients at 6 to 12 months [4,23-26]. However, there is no clear evidence suggesting the usefulness of diagnostic WBS on intermediate-risk patients. Therefore, this study aims to evaluate whether diagnostic WBS at 6 to 12 months after remnant ablation is necessary for intermediate-risk patients who have differentiated thyroid carcinoma after total thyroidectomy and have been treated with $1,100 \mathrm{MBq}(30 \mathrm{mCi})$ radioiodine thyroid ablation.

\section{METHODS}

This study included 438 patients with differentiated thyroid carcinoma who had undergone $30 \mathrm{mCi}$ radioiodine thyroid ablation between January 2003 and December 2011. According to the ATA's 2009 revised guideline for thyroid nodule and cancer treatment, low-risk and intermediate-risk groups have been established to reflect the presence of residual lesions and risk of relapse. A low-risk patient is defined by: 1) no local and distant metastasis; 2) all macroscopic tumor has been resected; 3 ) there is no tumor invasion of locoregional tissues or structures; 4) the tumor does not have aggressive histology (e.g., tall cell, insular, columnar cell carcinoma) or vascular invasion; and 5) if I-131 is given, there is no I-131 uptake outside the thyroid bed on the first posttreatment whole-body radioactive iodide scan. Intermediate-risk patients have any of the following: 1) microscopic invasion of tumor into the perithyroidal soft tissue at initial surgery; 2) cervical lymph node metastases or I-131 uptake outside the thyroid bed on the whole-body radioactive iodide scan done after thyroid remnant ablation; and 3) tumor with aggressive histology or vascular invasion [4].

The post-therapeutic WBS was performed on the third day after administrating $30 \mathrm{mCi}$ radioiodine (I-131) in the sixth week after total thyroidectomy. Pretreatment was as follows: the patients underwent thyroid hormone withdrawal to increase the radioiodine uptake in residual thyroid tissue. Thyroxine was discontinued 4 weeks before ablation. Instead of thyroxine, triiodothyroxine $(20 \mu \mathrm{g})$ was given orally twice a day for 2 weeks.Triiodothyroxine was withdrawn, and the patients were instructed to follow a low-iodine diet for 2 weeks before ablation. Before I-131 administration, serum thyroid stimulating hormone (TSH), free T4, T3, TSH-stimulating thyroglobulin (Tg; reference, 1.4 to $78.0 \mathrm{ng} / \mathrm{mL}$ ), and antithyroglobulin antibody (anti-Tg Ab, negative $<100 \mathrm{IU} / \mathrm{mL}$ ) were measured [27]. For all patients, TSH increased to above $30 \mathrm{mU} / \mathrm{L}$ after thyroid hormone withdrawal [27]. Diagnostic WBS was performed at 6 to 12 months after radioiodine thyroid ablation. The $3 \mathrm{mCi}$ dose was administered 3 days prior to scanning, and then a $\gamma$ camera was used to shoot for 13 minutes (Millennium GE, Israel). Prior to diagnostic WBS, TSH, free T4, T3, TSH-stimulating $\mathrm{Tg}$, and $\mathrm{Tg} \mathrm{Ab}$ were measured as a follow-up test. The presence of a relapse was confirmed by the results of ultrasound-induced fine needle aspiration cytology and surgical histopathology from the suspicious region on neck ultrasonography. Electric chemiluminescence immunoassays (Roche Diagnostics, Mannheim, Germany) were used to measure TSH, free T4, and T3, and enzyme immunosorbent assay (Alisei, SEAC, Pomezia, Italy) was used to measure $\mathrm{Tg}$ and $\mathrm{Tg} \mathrm{Ab}$. The mean comparison of the two groups was performed with $t$ test or Mann-Whitney $U$ test. The categorical variables are presented as numbers and percentages, and they were compared using the chi-square test or Fisher exact test. $P<0.05$ were statistically considered significant. All the statistical analyses were performed using SPSS version 12.0 for Windows (SPSS Inc., Chicago, IL, USA).

\section{RESULTS}

\section{Clinicopathologic characteristics of low-risk and intermediate-risk patients}

Total of 438 patients was observed. Most were diagnosed with papillary carcinoma with no histology of poor prognosis. There were 183 patients in the low-risk group, and 255 patients in the intermediate-risk group. There were no significant differences in age or sex between the two groups $(P=0.828$ and $P=0.106$, respectively). The AJCC TNM clinical stage was significantly lower for low-risk patients than for intermediate-risk patients $(P<0.001)$. The size of the thyroid tumor was similar between the two groups: $1.22 \pm 0.92 \mathrm{~cm}$ in intermediate-risk patients and $1.11 \pm 0.78 \mathrm{~cm}$ in low-risk patients $(P=0.170)$. The period 
during follow-up was 4.42 years (range, 1.33 to 8.75 ) for lowrisk patients and 3.25 years (range, 1.17 to 8.17 ) for intermediate-risk patients $(P<0.001)$ (Table 1$)$.

\section{Comparison of diagnostic whole-body scan uptake after radioactive iodine ablation according to risk group}

Patients received diagnostic I-131 WBS at 6 to 12 months with radioiodine ablation after total thyroidectomy. Blood tests performed at thyroid hormone withdrawal before diagnostic WBS. The $96.1 \%$ of low-risk patients and $93.6 \%$ of intermediate-risk patients had Tg levels below $2 \mathrm{ng} / \mathrm{mL}$ in the absence of $\mathrm{Tg} \mathrm{Ab}$, representing no significant difference $(P=0.259)$. At diagnostic WBS, 95.1\% of low-risk patients and 91.4\% of intermediate-risk patients had no I-131 uptake outside the thyroid bed. There was no significant difference between the two groups $(P=0.135)$. The scan result also suggested no local and distant metastasis except the thyroid bed (Table 2). Confirming the presence of a recurrence, $1.8 \%$ of intermediate-risk patients and $0.0 \%$ of low-risk patients had recurrence of thyroid cancer, showing no statistically significant differences $(P=0.089)$.

\section{Clinicopathologic characteristics according to diagnostic whole-body scan results in intermediate-risk patients}

The clinicopathologic characteristics according to the results of diagnostic WBS in intermediate-risk patients were observed

Table 1. Clinicopathologic Parameters of the Low- and Intermediate-Risk Groups

\begin{tabular}{lccc}
\hline Variable & $\begin{array}{c}\text { Low-risk } \\
(n=183)\end{array}$ & $\begin{array}{c}\text { Intermediate- } \\
\text { risk }(n=255)\end{array}$ & $P$ value \\
\hline Age, yr & $52(22-84)$ & $53(24-80)$ & 0.828 \\
Gender & $13(7.1)$ & $30(11.8)$ & 0.106 \\
$\quad$ Male & $170(92.9)$ & $225(88.2)$ & \\
Female & $1.11 \pm 0.78$ & $1.22 \pm 0.92$ & 0.170 \\
Tumor size, cm & $159(86.9)$ & $33(12.9)$ & \\
TNM staging & $15(8.2)$ & $57(22.4)$ & \\
I & $9(4.9)$ & $161(63.1)$ & \\
II & 0 & $4(1.6)$ & \\
III & & & \\
IV & $180(98.4)$ & $251(98.4)$ & \\
Histology & $3(1.6)$ & $4(1.8)$ & \\
Papillary & & & \\
Follicular & & & \\
Follow-up duration, yr $4.42(1.33-8.75)$ & $3.25(1.17-8.17)$ & $<0.001$ \\
\hline Values are expressed as median (range), number $(\%)$, or mean \pm SD. \\
TNM, tumor node metastasis.
\end{tabular}

(Table 3). Among 255 intermediate-risk patients, 233 had no uptake in the thyroid bed, and 22 had uptake on the thyroid bed. On diagnostic WBS, the group showing uptake in the thyroid bed had significantly smaller tumors than the group with no uptake $(0.78 \pm 0.48 \mathrm{~cm}$ vs. $1.26 \pm 0.94 \mathrm{~cm}$, respectively; $P=$ $0.020)$, higher lymph node metastasis $(86.4 \%$ and $59.7 \%$, respectively; $P=0.014), \mathrm{Tg}$ levels below $2 \mathrm{ng} / \mathrm{mL}$ in the absence of $\mathrm{Tg} \mathrm{Ab}(77.3 \%$ and $95.2 \%$, respectively; $P=0.001)$. There was no statistically significant between thyroid intake and age, sex, TNM stage, or Tg Ab.

The presence of uptake in thyroid bed on diagnostic whole-body scan and the recurrence according to thyroglobulin levels in intermediate-risk patients

We performed a blood test before diagnostic WBS after radioiodine ablation on intermediate-risk patients, and the scan results were compared between patients with negative $\mathrm{Tg} \mathrm{Ab}$, dividing the results of TSH-stimulating Tg levels into two groups based on levels below $2 \mathrm{ng} / \mathrm{mL}$ and above $2 \mathrm{ng} / \mathrm{mL}$ (Table 4).

Table 2. Comparison of Diagnostic Whole-Body Scan Findings after Radioactive Iodide Ablation according to Risk Group

\begin{tabular}{lccc}
\hline Variable & $\begin{array}{c}\text { Low-risk } \\
(n=183)\end{array}$ & $\begin{array}{c}\text { Intermediate-risk } \\
(n=255)\end{array}$ & $P$ value \\
\hline Postablation scan & & $17(6.7)$ & 0.445 \\
No detectable uptake & $9(4.9)$ & $238(93.3)$ & \\
Uptake in thyroid bed & $174(95.1)$ & 0 & \\
Metastasis & 0 & & 0.656 \\
Pre-Tg Ab & & $27(10.6)$ & \\
Presence & $17(9.3)$ & $228(89.4)$ & \\
Absence & $166(90.7)$ & $129(50.6)$ & 0.468 \\
Stimulated Tg <2 ng/mL & $99(54.1)$ & & 0.135 \\
Diagnostic WBS & & $233(91.4)$ & \\
No detectable uptake & $174(95.1)$ & $22(8.6)$ & \\
Uptake in thyroid bed & $9(4.9)$ & 0 & 0.870 \\
Metastasis & 0 & & \\
Post-Tg Ab & & $5(2.0)$ & \\
Presence & $4(2.2)$ & $250(98.0)$ & \\
Absence & $179(97.8)$ & $234(93.6)$ & 0.259 \\
Stimulated Tg <2 ng/mL & $172(96.1)$ & & \\
Recurrence & 0 & & \\
\hline
\end{tabular}

Values are expressed as number (\%). $P<0.05$.

Pre, before radioactive iodide ablation; $\mathrm{Tg}$, thyroglobulin; Ab, antibody; WBS, whole-body scan; Post, just before diagnostic WBS. 
On diagnostic WBS, 16 out of 250 patients (6.4\%) had Tg levels higher than $2 \mathrm{ng} / \mathrm{mL}$, and these patients also had a significantly higher uptake in thyroid bed compared to the below $2 \mathrm{ng} /$ $\mathrm{mL}$ group $(31.2 \%$ and $7.3 \%$, respectively; $P=0.008)$. However, the recurrence of thyroid cancer was not statistically significant $(n=1[6.2 \%]$ and $n=3[1.3 \%]$, respectively; $P=0.234)$. The clinical pathology of relapsed patients is described in Table 5.

\begin{tabular}{|c|c|c|c|}
\hline \multirow[b]{2}{*}{ Variable } & \multicolumn{2}{|c|}{ Intermediate-risk $(n=255)$} & \multirow[b]{2}{*}{$P$ value } \\
\hline & $\begin{array}{l}\text { No uptake } \\
(n=233)\end{array}$ & $\begin{array}{c}\text { Uptake in thyroid } \\
\text { bed }(n=22)\end{array}$ & \\
\hline Age, yr & $54(24-80)$ & $50.5(30-74)$ & 0.312 \\
\hline Gender & & & 0.731 \\
\hline Male & $27(11.6)$ & $3(13.6)$ & \\
\hline Female & $206(88.4)$ & $19(86.4)$ & \\
\hline Tumor size, cm & $1.26 \pm 0.94$ & $0.78 \pm 0.48$ & 0.020 \\
\hline $\begin{array}{l}\text { Extrathyroid } \\
\text { invasion, no/yes }\end{array}$ & $\begin{array}{l}98(42.1) / \\
135(57.9)\end{array}$ & $\begin{array}{c}14(63.6) / \\
8(36.4)\end{array}$ & 0.051 \\
\hline $\begin{array}{l}\text { Lymph node } \\
\text { metastasis, no/yes }\end{array}$ & $\begin{array}{l}94(40.3) / \\
139(59.7)\end{array}$ & $\begin{array}{l}3(13.6) / \\
19(86.4)\end{array}$ & 0.014 \\
\hline TNM staging & & & 0.384 \\
\hline I & $31(13.3)$ & $2(9.1)$ & \\
\hline II & $49(21.0)$ & $8(36.4)$ & \\
\hline III & 149 (63.9) & $12(54.5)$ & \\
\hline IV & $4(1.7)$ & 0 & \\
\hline Post-Tg Ab & & & 0.488 \\
\hline Presence & $5(2.1)$ & 0 & \\
\hline Absence & $228(97.9)$ & $22(100.0)$ & \\
\hline Stimulated $\mathrm{Tg}<2 \mathrm{ng} / \mathrm{mL}$ & $217(95.2)$ & $17(77.3)$ & 0.001 \\
\hline Recurrence & $3(1.3)$ & $1(4.5)$ & 0.240 \\
\hline
\end{tabular}

Values are expressed as median (range), number (\%), or mean \pm SD. TNM, tumor node metastases; Post, before diagnostic whole-body scan; Tg, thyroglobulin; Ab, antibody.

\section{DISCUSSION}

In this study, based on a diagnostic I-131 WBS performed at 6 to 12 months, 255 intermediate-risk patients and 183 low-risk patients diagnosed with differentiated thyroid carcinoma who were initially treated total thyroidectomy and $30 \mathrm{mCi}$ radioiodine ablation had no statistically significant difference in residual tissue removal rate $(95.1 \%$ and $91.4 \%$, respectively; $P=$ 0.135). With TSH-stimulating Tg level below $2 \mathrm{ng} / \mathrm{mL}$ in the absence $\mathrm{Tg} \mathrm{Ab}$, no significant difference was found between intermediate- $(93.6 \%)$ and low-risk $(96.1 \%)$ groups $(P=0.259)$. Intermediate-risk patients were divided into two groups of TSH-stimulating Tg, below $2 \mathrm{ng} / \mathrm{mL}$ and above $2 \mathrm{ng} / \mathrm{mL}$ in the absence $\mathrm{Tg}$ Ab during follow-up before diagnostic WBS. The results of diagnostic WBS were statistically significant differences; $92.7 \%$ of the below $2 \mathrm{ng} / \mathrm{mL}$ group and $68.8 \%$ of the above $2 \mathrm{ng} / \mathrm{mL}$ group had no uptake in the thyroid bed $(P=0.008)$. These results suggest that TSH-stimulating Tg impacts radioiodine uptake in remnant tissue. During follow-up, four recurrent patients were observed with local recurrence of lymph node metastasis, and most were not observed for thyroid

Table 4. Diagnostic Whole-Body Scan Results and Recurrence of Intermediate-Risk Patients, according to Thyroid Stimulating Hormone-Stimulated Thyroglobulin Level in the Absence of Antithyroglobulin Antibody (Total, $n=250$ )

\begin{tabular}{lclc}
\hline Variable & $\begin{array}{c}\mathrm{Tg}<2, \mathrm{ng} / \mathrm{mL} \\
(n=234)\end{array}$ & $\begin{array}{c}\mathrm{Tg} \geq 2, \mathrm{ng} / \mathrm{mL} \\
(n=16)\end{array}$ & $P$ value \\
\hline Diagnostic WBS & & & 0.008 \\
No detectable uptake & $217(92.7)$ & $11(68.8)$ & \\
Uptake in thyroid bed & $17(7.3)$ & $5(31.2)$ & \\
Metastasis & 0 & 0 & \\
Recurrence, no/yes & $231(98.7) / 3(1.3)$ & $15(93.8) / 1(6.2)$ & 0.234
\end{tabular}

Values are expressed as number (\%).

$\mathrm{Tg}$, thyroglobulin; WBS, whole-body scan.

Table 5. Summary of Clinicopathologic Data of the Four Patients with Recurrence

\begin{tabular}{|c|c|c|c|c|c|c|c|c|c|c|c|}
\hline \multirow{2}{*}{ Paitent } & \multirow{2}{*}{$\begin{array}{l}\text { Age, } \\
\text { yr/sex }\end{array}$} & \multirow{2}{*}{$\begin{array}{c}\text { Tumor } \\
\text { size, } \mathrm{cm}\end{array}$} & \multirow{2}{*}{$\begin{array}{c}\text { Extrathyroid } \\
\text { invasion }\end{array}$} & \multirow{2}{*}{$\begin{array}{l}\text { LN } \\
\text { Mets }\end{array}$} & \multirow{2}{*}{$\begin{array}{c}\text { TNM } \\
\text { staging }\end{array}$} & \multicolumn{3}{|c|}{ Initial } & \multicolumn{3}{|c|}{ Follow-up } \\
\hline & & & & & & 1st WBS & $\mathrm{Tg}, \mathrm{ng} / \mathrm{mL}$ & $\mathrm{Tg} \mathrm{Ab}$ & Dx WBS & $\mathrm{Tg}, \mathrm{ng} / \mathrm{mL}$ & $\mathrm{Tg} \mathrm{Ab}$ \\
\hline 1 & $75 / \mathrm{F}$ & 1.5 & $\mathrm{Y}$ & $\mathrm{N}$ & 3 & Remnant & $<0.5$ & $(-)$ & $\mathrm{N}$ & $<0.5$ & $(-)$ \\
\hline 2 & $70 / \mathrm{F}$ & 2.8 & $\mathrm{Y}$ & Y & 3 & Remnant & 9.1 & $(-)$ & $\mathrm{N}$ & 0.803 & $(-)$ \\
\hline 3 & $47 / \mathrm{M}$ & 0.5 & $\mathrm{~N}$ & $\mathrm{Y}$ & 3 & Remnant & 8.6 & $(-)$ & Remnant & 2.6 & $(-)$ \\
\hline 4 & $61 / \mathrm{F}$ & 1.5 & $\mathrm{~N}$ & Y & 3 & Remnant & $<0.5$ & $(-)$ & $\mathrm{N}$ & $<0.5$ & $(-)$ \\
\hline
\end{tabular}

LN, lymph node; Mets, metastasis; TNM, tumor node metastasis; WBS, whole-body scan; Tg, thyroglobulin; Ab, antibody; Dx, diagnostic; F, female; Y, yes; N, no; Remnant, uptake in thyroid bed; M, male. 
bed uptake from the diagnostic WBS.

Cailleux et al. [28] conducted diagnostic WBS at 6 to 12 months after $3.7 \mathrm{GBq}(100 \mathrm{mCi})$ of radioiodine ablation on differentiated thyroid carcinoma patients treated with total thyroidectomy. Ninety-two percent of 256 patients had no uptake in the thyroid bed, while $8 \%$ of the patients had uptake. Therefore, measuring Tg after thyroid hormone withdrawal for detecting recurrence and metastasis of thyroid cancer has high sensitivity; however, diagnostic WBS performed during follow-up had no additional usefulness. Pacini et al. [17] reported similar results from 662 patients with $1,100 \mathrm{MBq}$ to $3.7 \mathrm{GBq}$ (30 to $100 \mathrm{mCi}$ ) of radioiodine remnant ablation. In our study, although low-risk (95.1\%/4.9\%) and intermediate-risk patients $(91.4 \% / 8.6 \%)$ had no statistically significant differences for uptake in the thyroid bed on diagnostic WBS, the results were similar to that of Cailleux et al. [28]. Therefore, this suggests that a low dose $(30 \mathrm{mCi})$ of radioiodine remnant ablation is not inferior on residual tissue removal compared to a high dose $(100 \mathrm{mCi})$. In addition, the presence of uptake on diagnostic whole-body was similar to the low in intermediate-risk patients as well as low-risk patients, which suggests that diagnostic WBS may not be useful for predicting the recurrence.

In this study, four intermediate-risk patients had recurrence of thyroid cancer during follow-up, and all were suspected to have local lymph node metastasis, based on neck ultrasonography and confirmed with fine needle aspiration cystology and surgical histology. Neck ultrasonography is a very sensitive examination that can detect cervical metastasis or local recurrence on differentiated thyroid carcinoma, and it also can find metastatic lesions on a patient who is negative for TSH-stimulating $\operatorname{Tg}[29,30]$. Like this, neck ultrasonography is sensitive for confirming recurrence of cancer in intermediate-risk patients. Three out of four patients had no detectable uptake of radioiodine on diagnostic WBS with TSH-stimulating Tg level below $2 \mathrm{ng} / \mathrm{mL}$ in the absence Tg Ab. Only one patient had uptake with TSH-stimulating Tg level above $2 \mathrm{ng} / \mathrm{mL}$ in the absence $\mathrm{Tg} \mathrm{Ab}$. Serum Tg measurement after thyroid hormone withdrawal is known to be highly sensitive test in identifying patients with persistent tumor [31]. However, since the three patients within the group who had recurrence had no uptake on diagnostic WBS, and a TSH-stimulating Tg level below $2 \mathrm{ng} /$ $\mathrm{mL}$, it turned out to be less useful. Instead, neck ultrasonography to detect lymph node recurrence seems to be useful even though TSH-stimulating Tg is below $2 \mathrm{ng} / \mathrm{mL}$. Therefore, the result of the diagnostic WBS may not be helpful for surveilling the recurrence risk for intermediate-risk patients. For this rea- son, diagnostic WBS may not be necessary 6 to 12 months after radioiodine ablation. However, there must be additional follow-up studies for patients with a high level of TSH-stimulating $\mathrm{Tg}$ measured at first radioiodine ablation.

This study has the following limitations. First, there was a possible selection bias since this study was a retrospective study conducted in single hospital and with a small scale group. Second, it was not easy to determine the correlation between the poor prognosis and papillary microcarcinoma accompanied by minimally extrathyroid extension. In our study, about $36 \%$ of patients showed papillary microcarcinoma with minimal extrathyroid extension. In these patients, it is controversial whether the initially radioiodine ablation is useful, and therefore this challenges the value of the WBS [32,33]. Third, considering the long-term survival rate of thyroid cancer patients, the mean period of follow-up was as short as 3 to 4 years, rendering few patients with recurrence.

In summary, TSH-stimulating Tg level, the most sensitive surveillance of residual thyroid cancer, reflected the radioiodine uptake on diagnostic WBS. In addition, considering the difficulties of pretreatment including exposure to I-131, expense, and low-iodine diet, diagnostic WBS after radioiodine ablation seems to be of little value for intermediate-risk patients, as it is for low-risk patients. However, a well-designed long-term and large-scale prospective multicenter study is needed to determine the main issues in the future.

\section{CONFLICTS OF INTEREST}

No potential conflict of interest relevant to this article was reported.

\section{REFERENCES}

1. Mazzaferri EL, Jhiang SM. Long-term impact of initial surgical and medical therapy on papillary and follicular thyroid cancer. Am J Med 1994;97:418-28.

2. Sherman SI. Thyroid carcinoma. Lancet 2003;361:501-11. 3. Shah MD, Hall FT, Eski SJ, Witterick IJ, Walfish PG, Freeman JL. Clinical course of thyroid carcinoma after neck dissection. Laryngoscope 2003;113:2102-7.

4. American Thyroid Association (ATA) Guidelines Taskforce on Thyroid Nodules and Differentiated Thyroid Cancer, Cooper DS, Doherty GM, Haugen BR, Kloos RT, Lee SL, Mandel SJ, Mazzaferri EL, McIver B, Pacini F, Schlumberger M, Sherman SI, Steward DL, Tuttle RM. Re- 
vised American Thyroid Association management guidelines for patients with thyroid nodules and differentiated thyroid cancer. Thyroid 2009;19:1167-214.

5. Schlumberger MJ. Papillary and follicular thyroid carcinoma. N Engl J Med 1998;338:297-306.

6. Samaan NA, Schultz PN, Hickey RC, Goepfert H, Haynie TP, Johnston DA, Ordonez NG. The results of various modalities of treatment of well differentiated thyroid carcinomas: a retrospective review of 1599 patients. J Clin Endocrinol Metab 1992;75:714-20.

7. Vini L, Harmer C. Radioiodine treatment for differentiated thyroid cancer. Clin Oncol (R Coll Radiol) 2000;12:36572.

8. Kim TY, Kim WB, Kim ES, Ryu JS, Yeo JS, Kim SC, Hong SJ, Shong YK. Serum thyroglobulin levels at the time of 131I remnant ablation just after thyroidectomy are useful for early prediction of clinical recurrence in lowrisk patients with differentiated thyroid carcinoma. J Clin Endocrinol Metab 2005;90:1440-5.

9. Davies L, Welch HG. Increasing incidence of thyroid cancer in the United States, 1973-2002. JAMA 2006;295: 2164-7.

10. Cooper DS, Doherty GM, Haugen BR, Kloos RT, Lee SL, Mandel SJ, Mazzaferri EL, McIver B, Sherman SI, Tuttle RM; American Thyroid Association Guidelines Taskforce. Management guidelines for patients with thyroid nodules and differentiated thyroid cancer. Thyroid 2006;16:109-42.

11. Brierley JD, Panzarella T, Tsang RW, Gospodarowicz MK, O'Sullivan B. A comparison of different staging systems predictability of patient outcome. Thyroid carcinoma as an example. Cancer 1997;79:2414-23.

12. Loh KC, Greenspan FS, Gee L, Miller TR, Yeo PP. Pathological tumor-node-metastasis (pTNM) staging for papillary and follicular thyroid carcinomas: a retrospective analysis of 700 patients. J Clin Endocrinol Metab 1997;82: 3553-62.

13. Wittekind C, Compton CC, Greene FL, Sobin LH. TNM residual tumor classification revisited. Cancer 2002;94: 2511-6.

14. Sherman SI, Brierley JD, Sperling M, Ain KB, Bigos ST, Cooper DS, Haugen BR, Ho M, Klein I, Ladenson PW, Robbins J, Ross DS, Specker B, Taylor T, Maxon HR 3rd. Prospective multicenter study of thyroiscarcinoma treatment: initial analysis of staging and outcome. National Thyroid Cancer Treatment Cooperative Study Registry Group. Cancer 1998;83:1012-21.
15. Torlontano M, Crocetti U, D'Aloiso L, Bonfitto N, Di Giorgio A, Modoni S, Valle G, Frusciante V, Bisceglia M, Filetti S, Schlumberger M, Trischitta V. Serum thyroglobulin and 131I whole body scan after recombinant human TSH stimulation in the follow-up of low-risk patients with differentiated thyroid cancer. Eur J Endocrinol 2003;148: 19-24.

16. Schlumberger M, Berg G, Cohen O, Duntas L, Jamar F, Jarzab B, Limbert E, Lind P, Pacini F, Reiners C, Sanchez Franco F, Toft A, Wiersinga WM. Follow-up of low-risk patients with differentiated thyroid carcinoma: a European perspective. Eur J Endocrinol 2004;150:105-12.

17. Pacini F, Capezzone M, Elisei R, Ceccarelli C, Taddei D, Pinchera A. Diagnostic 131-iodine whole-body scan may be avoided in thyroid cancer patients who have undetectable stimulated serum Tg levels after initial treatment. J Clin Endocrinol Metab 2002;87:1499-501.

18. Torlontano M, Attard M, Crocetti U, Tumino S, Bruno R, Costante G, D'Azzo G, Meringolo D, Ferretti E, Sacco R, Arturi F, Filetti S. Follow-up of low risk patients with papillary thyroid cancer: role of neck ultrasonography in detecting lymph node metastases. J Clin Endocrinol Metab 2004;89:3402-7.

19. Frasoldati A, Pesenti M, Gallo M, Caroggio A, Salvo D, Valcavi R. Diagnosis of neck recurrences in patients with differentiated thyroid carcinoma. Cancer 2003;97:90-6.

20. Frilling A, Gorges R, Tecklenborg K, Gassmann P, Bockhorn M, Clausen M, Broelsch CE. Value of preoperative diagnostic modalities in patients with recurrent thyroid carcinoma. Surgery 2000;128:1067-74.

21. Ronga G, Filesi M, Ventroni G, Vestri AR, Signore A. Value of the first serum thyroglobulin level after total thyroidectomy for the diagnosis of metastases from differentiated thyroid carcinoma. Eur J Nucl Med 1999;26:1448-52.

22. Toubeau M, Touzery C, Arveux P, Chaplain G, Vaillant G, Berriolo A, Riedinger JM, Boichot C, Cochet A, Brunotte F. Predictive value for disease progression of serum thyroglobulin levels measured in the postoperative period and after (131)I ablation therapy in patients with differentiated thyroid cancer. J Nucl Med 2004;45:988-94.

23. Cobin RH, Gharib H, Bergman DA, Clark OH, Cooper DS, Daniels GH, Dickey RA, Duick DS, Garber JR, Hay ID, Kukora JS, Lando HM, Schorr AB, Zeiger MA; Thyroid Carcinoma Task Force. AACE/AAES medical/surgical guidelines for clinical practice: management of thyroid carcinoma. American Association of Clinical Endocrinolo- 
gists. American College of Endocrinology. Endocr Pract 2001;7:202-20.

24. Taylor T, Specker B, Robbins J, Sperling M, Ho M, Ain K, Bigos ST, Brierley J, Cooper D, Haugen B, Hay I, Hertzberg V, Klein I, Klein H, Ladenson P, Nishiyama R, Ross D, Sherman S, Maxon HR. Outcome after treatment of high-risk papillary and non-Hurthle-cell follicular thyroid carcinoma. Ann Intern Med 1998;129:622-7.

25. Sawka AM, Thephamongkhol K, Brouwers M, Thabane L, Browman G, Gerstein HC. Clinical review 170: a systematic review and metaanalysis of the effectiveness of radioactive iodine remnant ablation for well-differentiated thyroid cancer. J Clin Endocrinol Metab 2004;89:3668-76.

26. Durante C, Haddy N, Baudin E, Leboulleux S, Hartl D, Travagli JP, Caillou B, Ricard M, Lumbroso JD, De Vathaire F, Schlumberger M. Long-term outcome of 444 patients with distant metastases from papillary and follicular thyroid carcinoma: benefits and limits of radioiodine therapy. J Clin Endocrinol Metab 2006;91:2892-9.

27. Edmonds CJ, Hayes S, Kermode JC, Thompson BD. Measurement of serum TSH and thyroid hormones in the management of treatment of thyroid carcinoma with radioiodine. Br J Radiol 1977;50:799-807.

28. Cailleux AF, Baudin E, Travagli JP, Ricard M, Schlumberger M. Is diagnostic iodine-131 scanning useful after total thyroid ablation for differentiated thyroid cancer? J Clin Endocrinol Metab 2000;85:175-8.
29. David A, Blotta A, Rossi R, Zatelli MC, Bondanelli M, Roti E, Braverman LE, Busutti L, degli Uberti EC. Clinical value of different responses of serum thyroglobulin to recombinant human thyrotropin in the follow-up of patients with differentiated thyroid carcinoma. Thyroid 2005; 15:267-73.

30. Pacini F, Molinaro E, Castagna MG, Agate L, Elisei R, Ceccarelli C, Lippi F, Taddei D, Grasso L, Pinchera A. Recombinant human thyrotropin-stimulated serum thyroglobulin combined with neck ultrasonography has the highest sensitivity in monitoring differentiated thyroid carcinoma. J Clin Endocrinol Metab 2003;88:3668-73.

31. Eustatia-Rutten CF, Smit JW, Romijn JA, van der KleijCorssmit EP, Pereira AM, Stokkel MP, Kievit J. Diagnostic value of serum thyroglobulin measurements in the followup of differentiated thyroid carcinoma, a structured metaanalysis. Clin Endocrinol (Oxf) 2004;61:61-74.

32. Kim HJ, Kim NK, Choi JH, Kim SW, Jin SM, Suh S, Bae JC, Min YK, Chung JH, Kim SW. Radioactive iodine ablation does not prevent recurrences in patients with papillary thyroid microcarcinoma. Clin Endocrinol (Oxf) 2013;78: 614-20.

33. Lim DJ, Baek KH, Lee YS, Park WC, Kim MK, Kang MI, Jeon HM, Lee JM, Yun-Cha B, Lee KW, Son HY, Kang SK. Clinical, histopathological, and molecular characteristics of papillary thyroid microcarcinoma. Thyroid 2007; 17:883-8. 